\title{
A new and rare species of Phlyctaeniella from central India
}

\section{Tiwari CK, Parihar Jagrati and Verma RK *}

Forest Pathology Division, Tropical Forest Research Institute, Jabalpur - 482021, Madhya Pradesh, India

Tiwari CK, Parihar Jagrati, Verma RK 2012 - A new and rare species of Phlyctaeniella from central India. Mycosphere 3(4), 450-453, Doi 10.5943 /mycosphere/3/4/8

Phlyctaeniella indica sp. nov. from Chhattisgarh State, India is described, illustrated and discussed. It is a rare species occurring on stored logs of Eucalyptus sp. and collected only once in the past 20 years from central India.

Key words - Ascomycete - pezizomycotina - taxonomy - wood depots

\section{Article Information}

Received 27 June 2012

Accepted 18 July 2012

Published online 15 August 2012

*Corresponding author: RK Verma - e-mail - rkverma28@rediffmail.com

\section{Introduction}

During the past two decades, 1529 specimens of wood decay fungi have been collected from central India and 182 species have been identified and reported on 51 woods including many new records of polypore fungi from India (Harsh et al. 1997, Tiwari et al. 1987, 1989, 2005, 2009, 2010, 2011, Verma et al. 2008).

The present paper describes, illustrates and discusses a new and rare species of Phlyctaeniella. Phlyctaeniella is an anamorph (coelomycete) of Pezizomycotina (ascomycete) similar to Septoria but septate and irregularly branched conidiophores of Phlyctaeniella separate it from Septoria in which conidiophores are absent.

\section{Methods}

Conventional morphology based taxonomic methods were employed. For microscopic study slides were prepared in lactophenol cotton blue mountant and in water. Photographs were taken with a Sony Cybershot camera, macroscopic and microscopic characters were studied under Wild M3Z and advanced research microscope, Leitz DMRB with digital EC3 camera. Camera lucida drawings were prepared using an Olympus research microscope. Identification was done with the aid of published works (Petrak 1922, 1929, Sydow 1930, Sutton 1980, Andrianova 1996). A key is provided to known species of Phlyctaeniella. The examined holotype specimen is deposited in the Mycology Herbarium, Forest Pathology Division, Tropical Forest Research Institute, Jabalpur, accession number TF 2681.

\section{Results}

After a study of 1529 specimens of fungi collected from stored logs in various wood depots of Chhattisgarh, Madhya Pradesh, Maharashtra and Orissa States of central India a single specimen was found of what proved to be a new species of Phlyctaeniella, which is described as follows:

Phlyctaeniella indica C.K. Tiwari, Parihar \& R.K. Verma sp. nov. Figs. 1-5 MB 800820

Etymology - named after the country of occurrence, India

Mycelium immersed, branched, septate, hyaline. Conidiomata eustromatic dark brownblack, surface rough, erumpent crusted, measuring 5-10 × 1.0-2.0 mm, composed of 4-15 chambers, each chamber consisting of a 

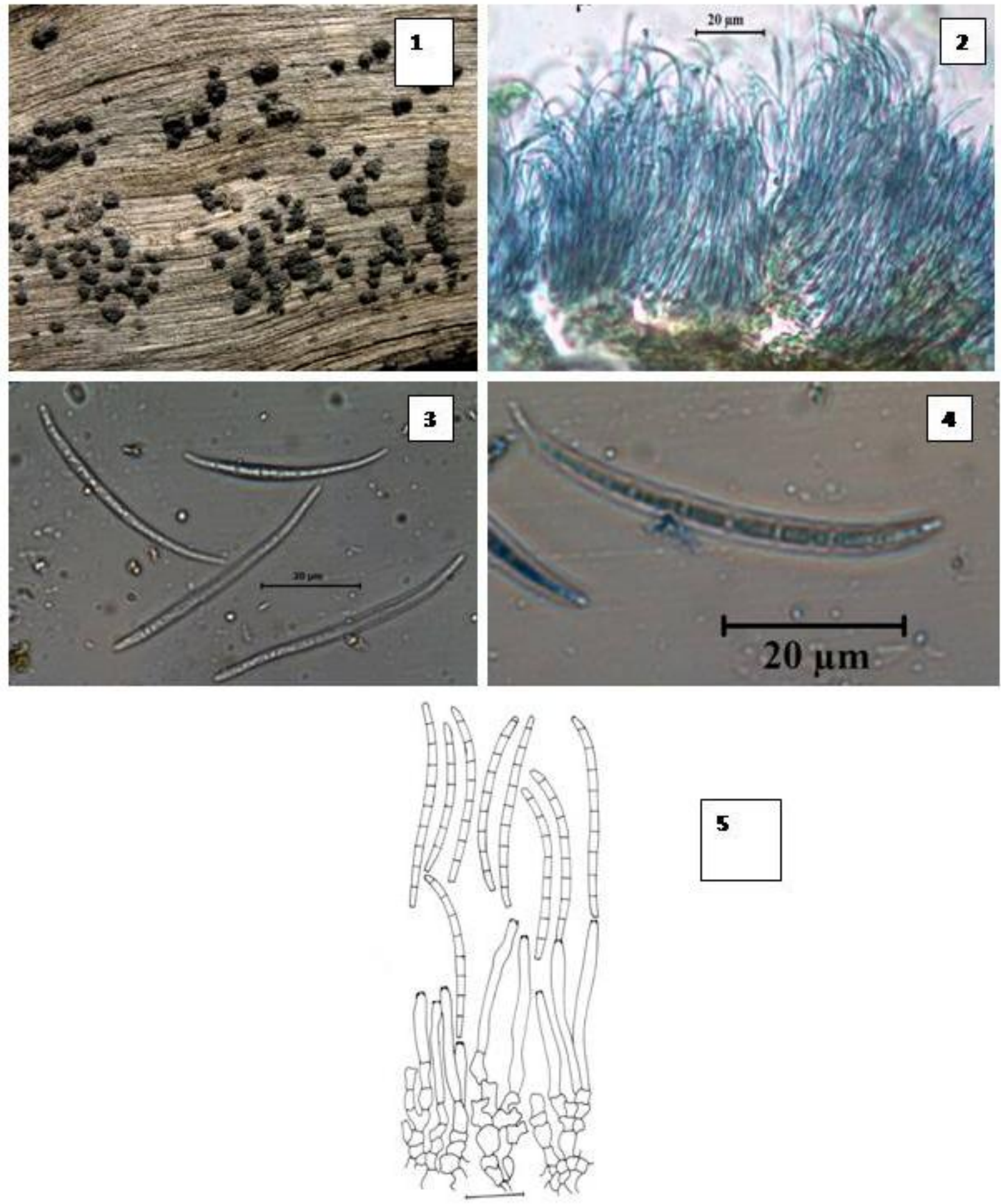

$\mathbf{5}$

Figs 1-5 - Phlyctaeniella indica 1 stromatic conidiomata. 2 inner wall cells of conidioma with conidiophores and conidia. 3-4 conidia and $\mathbf{5}$ conidiophores, conidiogenous cells and conidia. Scale bar $=20 \mu \mathrm{m}$ 


\section{Key to species of Phlyctaeniella}

1. Conidia up to $21 \mu \mathrm{m}$ long, conidiomata $90-130 \mu \mathrm{m}$, on leaves of Eucalyptus

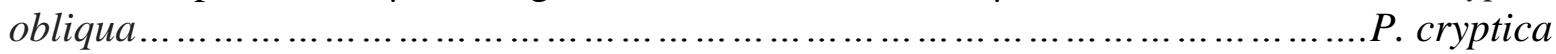

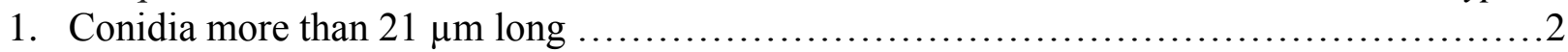

2. Conidia 33.5-58 $\times 4.5-7.5 \mu \mathrm{m}$, conidiophores $39.5-110 \times 5-8 \mu \mathrm{m}$, on logs of Eucalyptus

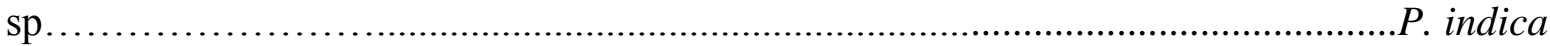

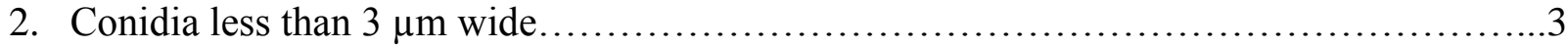

3. Conidia 25-45 × 1.5-2.0 $\mu \mathrm{m}$, conidiomata 220-350 $\mu \mathrm{m}$, on leaves of Aruncus sylvestris P. polonica

3. Conidia 34-55 $\times 2.5 \mu \mathrm{m}$, conidiophores $20 \times 2.5-3.0 \mu \mathrm{m}$, on stem of Humulus luplus P. humuli

3. Conidia $60 \times 3 \mu \mathrm{m}, 3$ septate, on leaves of Galium psilotum P. psilostega

well developed pycnidium; pycnidia dark brown, globose to involvulate, $385 \times 475 \mu \mathrm{m}$, wall several cells thick, inner side of wall containing hyaline thin-walled cells, outer cells are darker, ostiole indistinct, dehiscence by rupture of the upper wall. Conidiophores simple or irregularly branched, especially at the base, formed from the inner cells of the stromatal wall, hyaline, smooth-walled, septate, filamentous, loose to semi-compact, uniformly arranged, $39.5-110 \times 6.5-8.0 \mu \mathrm{m}$. Conidiogenous cell enteroblastic, phialidic integrated or discrete, determinate, hyaline, tapered at apices, smooth, with apical aperture, 15-21 x 23-25 $\mu \mathrm{m}$. Conidia abundant, hyaline, smooth, thin-walled, filiform, slightly curved at one end or sigmoid, 4-10 septate, 33.5-58 $\times$ $4.5-7.5 \mu \mathrm{m}$.

Habitat - On stored logs of Eucalyptus sp.

Known distribution - Marwahi, Bilaspur, Chhattisgarh, India

Material examined - INDIA, Chhattisgarh State, District Bilaspur, Marwahi wood depot, 28.7.2011, CK Tiwari and J Parihar, TF 2681, holotype

\section{Discussion}

The genus Phlyctaeniella was established by Petrak with its type species $P$. polonica Petr. (Petrak 1922). Since then only a further three species have been reported under this genus namely $P$. humuli Petr., $P$. psilostega (Ellis \& G. Martin) Andrian. and $P$. cryptica Syd. from Austria, USA and South Australia. $P$. psilostega was originally described as Septoria psilostega Ellis \& G. Martin and later transferred to Phlyctaeniella
(Andrianova 1996). Sutton (1980) gave an account of the genus based on the type specimen $P$. humuli. Species of this genus occur on leaves and stems. $P$. indica is compared with the other published species of Phlyctaeniella in the key. The conidia of $P$. indica are wider than those of other species including $P$. cryptica (2-3 $\mu \mathrm{m}$ wide) from other reported species. $P$. indica was collected on sapwood of stored logs of Eucalyptus sp. and no other Phlyctaeniella is reported on wood logs. This is the first time that a species of Phlyctaeniella has been reported from India.

\section{Acknowledgement}

The authors would like to thank Dr. U. Prakasham, Director, Tropical Forest Research Institute, Jabalpur, for providing laboratory facilities and CSIR, New Delhi for financial support.

\section{References}

Andrianova TV. 1996 - On the taxonomic position of some species of Septoria Sacc. described by von Moesz and Hollós. II. Mikologiya i Fitopatologiya 30, 3-13.

Harsh NSK, Bisht NS, Tiwari CK. 1997 - Two new wood-decaying fungi from India. The Indian Forester 123, 1001-1006.

Petrak F. 1922 - Mykologische Notizen IV. Annales Mycologici 20, 300-345.

Sutton BC. 1980. The Coelomycetes fungi imperfecti with pycnidia, acervuli and stromata. Commonwealth Mycological Institute, Kew Surrey, England.

Sydow H. 1930 - Novae fungorum species - 
XX. Annales Mycologici 28, 432-447.

Tiwari CK, Harsh NSK. 2005 - Wooddecaying fungi of teak from Madhya Pradesh, India. The Indian Forester 131, 215-220.

Tiwari DP, Harsh NSK, Tiwari CK. 1987 The genus Navisporus from India. Biome 2, 35-37.

Tiwari DP, Harsh NSK, Tiwari CK. 1989 Polypore flora of Jabalpur and its eastern suburbs. Biome 4, 69-79.

Tiwari CK, Harsh NSK, Jamaluddin 2005 Wood-decaying fungi of Boswellia serrata stored wood. The Indian Forester 131, 1071-1075.

Tiwari CK, Verma RK, Ayachi AK. 2008 Wood decaying polypore fungi of sal from Madhya Pradesh, India. Sci-fronts
2, 13-26.

Tiwari CK, Parihar J, Verma RK. 2009 Wood decaying fungi in forest wood depots of Chhattisgarh. Indian Journal of Tropical Biodiversity 17, 129-140.

Tiwari CK, Parihar J, Verma RK. 2010 Addition to the wood decaying fungi of India. Journal of Threatened Taxa 2, 970-973.

Tiwari CK, Parihar J, Verma RK. 2011 Hapalopilus nidulans (Polyporales: Polyporaceae) a new record from India. Journal of Threatened Taxa 3, 18721874.

Verma RK, Sharma Nidhi, Soni KK, Jamaluddin 2008 - Forest Fungi of Central India. International Book Distributing Company, Lucknow, India. 